FACULDADE DE MEDICINA DA UNIVERSIDADE DE SÃO PAULO
Cadeira de Terapêtutica Clínica. Prof. Cantidio de Moura Campos

DR. JOSE FERNANDES PONTES

(Assistente do Ambulatório de Gastro-Enterologia da Santa Casa, Chefe: Dri Levy Sodré Assistente voluntário de Terapêutica Clínica).

\title{
VALOR PROPEDÊUTICO DO EXAME COPROLÓGICO
}

Em vários estados mórbidos do aparelho gastro-intestinal o exame sistemático das fezes é imprescindivel para a melhor compreensão do processo patológico.

Quando realizado e interpretado criteriosamente, as informa. ções que este recurso propedêutico nos fornece dizem respeito a vários aspectos da fisiopatologia digestiva, isto é, ao trânsito intestinal, ao estado da parede cólica, aos desvios đa flora e ás disfunções secretoras deste ou daquele setor glandular. Aos poucos abordaremos cada um destes pontos.

Ha ainda controvérsias no tocante á necessidade de um regime alimentar prévio. Os que nã̃o recomendam este regime justificam a sua conduta nas possiveis alterações que a dieta padrão traria ao estado gastro-intestinal e consequente mascaração da situação real anterior. $\mathrm{Na}$ realidade, ás vezes, observamos o desaparecimento de uma diarréa durante os dias de regime de prova, sendo o material do exame menos fluído, de consistência habitual ou mesmo aumentada. A eventualidade oposta tambem se regista, isto é, estabeleci.. mento ou acentuação de diarréa com o referido regime.

Os partidários do regime preparatório se firmam em duas razões principais.

Em primeiro lugar, alguns dias de regime de prova não alterariam os caracteres fundamentais do quadro mórbido, em geral crônico, de que é séde o aparelho digestivo. Sabemos da energia e da persistência que devemos ter ao prescrevermos os regimes alimentares corretivos das grastro-enteropatias, mormente para eliminação do componente dispéptico a elas associado.

Em segundo lugar, mais importante, a padronização de um regime de prova facilita a feitura do exame e permite comparar os resultados obtidos, por assegurar a inclusão de todos os alimentos através de cujo estado de digestão é possivel a análise de todas as 
funções do aparelho gastro-intestinal (tubo e anexos). Do contrário, nunca poderiamos estar certos de que na alimentação de nossos pacientes figuram todos esses alimentos, e os resultados obtidos sempre estariam sujeitos a reservas sérias.

$O$ regime de prova que costumamos prescrever por 3 a 5 dias consta do seguinte:

Pela manhã e á tarde: 200 a $300 \mathrm{cc}$. de leite, puro ou com um pouco de café; 40 a 60 grs.d e pão torrado; 20 grs. de manterga. Isto em cada refeição.

No almoço e no jantar: 1 ovo quente; 80 a 120 grs. de carne mal passada, quasi crua; pirão de batatas e arroz á vontade. No jantar admitir ainda sopa de macarrão com cenouras.

Nunca é demais insistir com os doentes para seguirem exatamente o regime, em todos os seus pontos, principalmente no que diz respeito á carne quasi crua, á ingestão de manteiga, etc..

Todo o material evacuado na manhã do dia do exame deve ser considerado: Recomendar que o paciente não urine no frasco em que são colhidas as fezes, porquanto prejudicam-se vários resultados, como a dosagem do amoníaco, fator importante do síndroma da dispepsia putrefativa, como veremos. Caso haja prisão de ventre, ouprolongar o regime por mais um ou dois dias, ou colher o material mediante pequeno clister. $\mathrm{O}$ exame deve ser realizado o mais cedo possivel após a evacuação das fezes, dadas as possibilidades de desenvolvimențo de fermentações e putrefações. No máximo conservar por algumas horas o material em geladeira. Temos observado que o material guardado em geladeira, até 24 horas, não apresenta alterações sensiveis em seus vários caracteres. Preferir, entretanto, sempre o exame imediato. Dividiremos o exame coprológico em 3 secções: A) Exame macroscópico; B) Exame microscópico; C) Exame químico.

A) Exame macroscópico: Inclue a análise dos caracteres exteriores do material (consistência, forma, cheiro, côr, reação, aspecto) e pesquisa de restos alimentares.

Normalmente, com o regime de prova mencionado, as fezes são de consistência habitual, cilíndricas, de cheiro "sui generis", marrons e de reação neutra ou levemente alcalina. Já nos desvios destes caracteres exteriores normais, ensinamentos preciosos e orientadores dos exames subsequentes podem ser apreendidos. Assim, nas diarréas de tipo fermentativo, as fezes são pastosas ou inteiramente líquidas, amarelo-claras, de cheiro "ácido" penetrante, lembrando manteiga rançosa ou abacaxí passado, de reação ácida, com bolhas gasosas que se manteem presas em meio ao material, dando-lhe aspecto esponjaso e que arrebentam 'quando se revolvem as fezes com um bastão. Tal é o aspecto exterior das fezes na dispepsia fermentativa clássica, tão bem descrita por Ad. Schmidt.

Frizemos, entretanto, desde já, que um, alguns ou mesmo todos estes caracteres macroscópicos podem, se ausentar numa dispepsia 
fermentativa que, então, só é surpreendida mediante o exame quimico e microscópico que adeante descreveremos. Destes elementos os mais frequentes são a consistência mole e a reação ácida ao tornasol. Podem, entretanto, mesmo estes sinais estar ausentes na dispepsia fermentativa e, na aparência, pelos caracteres exteriores, as fezes serem inteiramente normais. A explicação é a seguinte: Se, apesar da atividade exagerada da flora fermentativa, com a produção consequente excessiva dos ácidos orgânicos, irritantes da mucosa intestinal, o trânsito não se acelerar, ou se acelerar pouco no hemicolon direito, a absorção da água do material intestinal far-se-á normalmente ou quasi. As fezes serão, então, da consistência hábitual normal, ou proximamente. Por outro lado, os ácidos orgânicos, cujo excesso determina a reação ácida (sempre patológica) rlas fezes ao tornasol, irritam demasiadamente a paređe cólica e esta responde com excesso de secreção. A secreção é rica em valências alcalinas (catiões) e ao mesmo tempo é meio favoravel ao crescimento da flora putrefativa que produzirá em exagero amoníaco. A soma das valências básicas correspondentes ao amoníaco e aos ca-tiões, já referidas, pỏderá ser suficiente para neutralizar as valências ácidas dos produtos fermentativos, con sobra mesmo. Ficam assim explicados os casos de dispepsias fermentativas com reação neı1tra ou alcalina das fezes. Eis porque Goiffon considera em segunda plana estes caracteres exteriores das fezes no diagnóstico das dispepsias fermentativas, dando muito valor á dosagem dos ácidos orgânicos de fermentação.

Menos sujeitas a variações de seu aspecto exțerior são as fezes das dispepsias putrefativas. Mostram-se pastosas ou liquidas, pardoescuras, de cheiro pútrido (de ovos podres ou de gás sulfídrico), de reação fortemente alcalina.

A consistência das fezes depende fundamentalmente da velocidade do trânsito pelo colon direito (céco-ascnecente e metade direita ou pouco mais do transverso). Com efeito, é nesta região que o conteudo intestinal se concentra, graças á absorção da água, atingindo o ângulo esplênico do colon já com a consistência aproximada do material exonerado. E facil compreender, a vista destas noções, que a fluidez das fezes diarrêicas dependa da aceleração da passagem do conteudo intestinal pela primeira metade do colon, não havendo tempo suficiente para a absorção da água.

As fezes endurecidas, eliminadas em cíbalas, indicam excesso de absorção de água em virtude de permanência anormalmente prolongada do bolo fecal nos colons, quer por hipotonia da musculatura cólica (prisão de ventre atônica), quer por hipertonia discinética dos movimentos dos colons (prisão de ventre espástica).

Quanto ao aspecto assinalemos que, em geral, quando as fezes não ẽncontram obstáculos ao seu livre trânsito pelos .colons, se eliminam com a consistência mais ou menos igual em todas as suas porções. São homøgêneas. Se porém, esse obstáculo surgir, seja 
ele funcional ou - e é o que se dá com maior frequência, - consubstrato anatómico, como uma obstruçãoo parcial da lưz intestinal por uma causa qualquer (estenose cicatricial, neoplasias, etc.) o material se retem à montante e se endurece devido ao excesso de absorção de líquidos. A esta coprostase o colon reage de duas maneiras: com aumento de secreção que dilue parte do material, e, com hipercinesia. Vencido o obstáculo, graças a uma onda de contração mais forte da musculatura á montante, eliminam-se fezes líquidas de mistura com porções ainda endurecidas. São as fezes heterogeneas, das falsas diarréns que trazem a suspeita de estreitamento situato em um nivel qualquer do colon.

É um sinal importante de estreitamento baixo retal ou ano-retal, a verificação de fezes de fórma achatada, comparavel a fita.

A côr das fezes é principalmente determinada pela estercobilina, substância derivada da bilerrubina, passando pela fase de estercobilinogênio. A transformação de um pigmento em outro se dá na regiã̃o íleo-cecal. Mais adeante, a propósito das reações químicas, veremos o valor da pesquisa do estado em que se acha cada um destes pigmentos. Geralmente as fezes das dispepsias putrefativas são escuras em virtude do meio alcalino favorecer a formação da estercobilina. Podem entretanto as feses desta dispepsia ser claras, lembramos fezes acólicas. A distinção entre ambas as eventualidades se fàz mediante a reação do sublimado e de Grigaut (v. reações químicas)!

Já as fezes das dispepsias fermentativas são amarelo-claras. Mais claras são as fezes acólicas, em razão da ausêncià dos pigmentos de origem biliar.

Prosseguindo no exame coprológico, verificados os caracteres exteriores mencionados, deve-se, após diluição do material em água adicionada lentamente, procurar: 1) restos alimentares de origem animal, e de origem vegetal e, 2) produtos de origem intestinal.

Restos alimentares: 'É valioso o encontro de tecido conjuntivo, principalmente sob a forma de filamentos grossos ou de membranas. Sabe-se hoje que o tecido conjuntivo crú, assim como a pectina que constitue a substância cimentante, que une as células dos vegetais entre si, só se dissolvem guando sofrem ação adequada do ácido clorídrico do suco gástrico. $O$ encontro, portanto, nas fezes de um indivíduo submetido ao regime de prova, (que contém tecido conjuntivo crú na carne mal passada) de tecido conjuntivo macroscopicamente visivel, e de pedaços de cenoura ou de batata (indicando que a pectina não foi dissolvida), são os sinais mais seguros de digestão gástrica insuficiente. Note-se que dizemos digestão gástrica insuficiente, isto é, tanto pode a insuficiência da digestão correr por conta de hipossecreção, como por esvasiamento gástrico muito rápido. Do ponto de vista prático, em grande número de casos trata-se de aquilia ( $V$ observação n. ${ }^{0}$ 2). Mesmo nos casos de esvasiamento gástrico acelerado, sem aquilia. a acides 
gástrica costuma estar baixa. Compreende-se o valor de tal achado, indicando imediatamente a terapêutica a ser adotada. Outro sinal, menos importante, denotador de insuficiência gástrica, é o encontro de cristais de oxalato de cálcio de procedência alimentar. Tais 'cristais, á diferença dos de origem intestinal, formados nas fermentações que aí se processam, são prismáticos e não com a forma de envelope de cartas. (Goiffon). Ailem disto se acham incluidos em cêlulas, como as do feijão. Normalmente, estes cristais, passando pelo estômago, se dissolvem por reagirem com o ácido clorídrico, resultando ácido oxálico e cloreto de cálcio, ambos hidros soluveis. A' sua presença nas fezes indica, portanto, ausência de ácido clorídrico no estômago.

O aparecimento de pedaços de carne visiveis macroscopicamente atesta, ao mesmo tempo, má digestão do tecido conjuntivo e do tecido muscular. Necessitando o tecido conjuntivo crú para a sua digestão da ação do suco gástrico como já vimos, e o tecido muscular sendo atacado sòmente pelo suco pancreático, deduz-se que a presença de carne nas fezes se 'subordina a duas condições: insuficiência da digestão gástrica, por não ter sido digerido o tecido conjuntivo que reune as fibras musculares, e insuficiência da digestão pancreática, pela presença de fibras musculares intactas.

O encontro de pedlaços de batata tem o mesmo valor que o de pedaços de cenoura. Em um e outro caso conclue-se que a substância intercelular, que mantem unidas as celulas desses alimentos, nã்o se dissolveu por deficiente digestão no estồmago.

Como restos alimentares podemos encontrar ainda ao exame macroscópico, gorduras que sobrenadam a água com que se diluem as fezes. Estas substâncias, em grande quantidade, só são verificadas nas esteatorréas intensas da insuficiência. pancreática grave, do esprú, etc.

Como produtos de origem intestinal consideraremos o muco, o sangue e o pús.

O muco, ao influxo principalmente das idéas de Schmidt, foi por muito tempo considerado como sinal patognomônico de estado inflamatório, infeccioso dá mucosa intestinal. Hoje não mais se admite esta relação tão estrita de causa e efeito entre presença de muco nas fezes e infecção entero-cólica. É necessảrio antes de tudo ter-se em menté que o muco é produzido normalmente em todas as porções do aparelho digestivo em que se encontrem células mucíparas, como no estômago, no intestino delgado, nos colons. Permite mais facil deslișamento entre a mucosa gastro-entérica e o conteudo do tubo digestivo. Este muco, que é então um produto habitual de secreção da mucosa digestiva, reabsorve-se normalmente, não aparecendo como tal nas fezes emitidas. Sempre, entretanto, que a quantidade de muco secretado aumente, ou que o trânsito intestinal se acelere Cemasiadamente, ha a possibilidade deste material aparecer nas evacuaçōes, tudo dependendo da séde em que o exagero de produção se 
der e da aceleração do trânsito intestinal a partir deste ponto. Entre as causas que mais frequentemente aumentam a produção de muco se acham as inflamatórias, sejam elas infecciosas (protozoários, bactérias, etc.) ou simplesmente de natureśa química ou mecânica. Entre as de natureza química se acha o estímulo exercido pelos ácidos orgânicos de fermentação quando produzidos em excesso, acarretando não só aceleração do peristaltismo, como produção aumentada de muco. Se a aceleração do trânsito for de tal intensidade que não permita a reabsorção do muco secretado, este se eliminará. O mesmo raciocínio poderá ser aplicado nas eventualidades em que o estímulo seja representado por um agente infeccioso.

As causas irritativas đe naturesa mecânica acima aludidas são constituidas principalmente por material fecal endurecido, tal qual se encontra na obstirpação. Como defesa contra este conteudo de dureza aumentada, lança mão o intestino de maior quantidade de seu lubrificante natural. Eis a razão por que, envolvendo ou precedendo as fezes duras dos obstipados crônicos, se encontra com grande frequência o muco.

Os nossos conhecimentos hoje vão mais longe acerca das causas capazes de exagerar a produção de muco no aparelho digestivo. Sabe-se que influxos simplesmente nervosos podem originar esse aumento, por vezes de maneira surpreendente. O exemplo mais ilustrativo é o da chamada colite muco-membranosa ou melhor denominada por Von Noorden "mixoneurose intestinal pseudo-membranosa crônica". Esta afecção se caracteriza essencialmente pela eliminação de fezes, em geral em cíbalas, acompanhadas de grande quantidade de muco. Este muco reveste a forma de membranas ou mesmo de tubos, e pode constituir o único material exonerado. Von Noorden considera como principal fator desta afecção uma hiperparassimpaticotonia no setor intestinal. Em grande número de casos não conseguiu evidenciar nenhum sinal de infecção das paredes intestinais. Estes sinais existiriam somente nas formas mixtas da moléstia, isto é, nas formas em que, ao componente funcional, se somasse uma infecção.

'A' vista do que ficou exposto, é lícito dizer-se que só se pode dar valor á presença de muco nas fezes, tendo-se conhecimento dos demais elementos do exame coprológico e mesmo do quadro clínico.

Em outra ordem de idéias, procurou-se, pelos caracteres que o muco tem nas fezes, estabelecer-lhe a procedência, se do intestino delgado ou do grosso. De modo geral, admite-se que o muco provém de zonas tanto mais altas quanto mais misturado se acha ás fezes e menores os pedaços em que se apresente dividido. São característicos de origem cólica os blocos maiores de muco, colocados perifèricamente no bolo fecal. Os grumos grandes eliminados na frente do material fecal ou sós, são próprios do sigmoide e do retọ. Von Noorden assim se exprime a respeito desta questão: "A admissão de que o muco procede do intestino delgado só é permitida quando 
ele se elimina em pequenas partículas no meio de deposições líquidas, e a justiça desta admissão aumenta quando estas partículas conteem bilerrubina, especialmente se esta substância reveste a forma de grânulos ou de cristais"... e mais adiante: "Geralmente os grumos de muco procedentes do intestino delgado são pobres de células, mas. ricos de bactérias e conteem ainda restos de fibras musculares e de outros alimentos".

Examinado ao microscópio, encerra o muco maior ou menor quantidade de células (células epiteliais, leucocitos e hemácias). Nos processos inflamatórios infecciosos intensos esses elementos, principalmente os leucocitos, se acham em grande quantidade, degenerados e aglutinados.

$E^{\prime}$ interessante assinalarem-se as verificações feitas por Goiffon de que, ás vezes, nas colites crônicas e extensas, mormente tuberculosas, o muco desaparece em virtude da destruição de bôa parte das: células mucíparas. Diz então Goiffon que, de certo modo, a presença de muco nas deposições é indício de benignidade da colite, pois atesta presença de celulas mucíparas funcionantes e certo gráu de: integridade da mucosa.

Sangue e pús: A presença de sangue e pús nas fezes, reconheciveis a olho nú, é apanágio das lesões das últimas porções do colon e do reto. Quando estes elementos patológicos são vertidos em porções mais altas do intestino, só são percebidas macroscopicamente se houver aceleração do trânsito intestinal. Do contrário, dada a rápida desagregação que tanto as hemácias como os leucocitos sofrem na luz intestinal, o seu reconhecimento só se fará com o exame microscópico, ou apenas pela pesquisa dos corpos oriundos de sua decomposição (hemoglobina, albuminas soluveis), como veremos adeante.

Terminado o exame macroscópico das fezes, já fertil em ensinamentos de várias naturesà, como acabamos de verificar, devemos passar ao exame microscópico, que permite conhecimento mais profundo das condições do aparelho digestivo. Deixaremos de lado a: pesquisa de ovos de parasitas e de protozoários, por ser assunto melhor conhecido, para cuidarmos do valor representativo dos restos alimentares, dos produtos de origem intestinal e de alguns cristais.

As fibras musculares podem ser encontradas bem ou mal digeridas. Aquelas se identificam como formações alongadas ou ovalares, de bordos arredondados, sem estriação transversal. Existem normalmente em pequena quantidade. As fibras mal digeridas se caracterizam por dimensões maiores, por terem os bordos cortantes, percebendo-se nitidamente a estriação transversal e longitudinal. Sua presença nas fezes é tida por Goiffon como um dos sinais mais precoces de insuficiência pancreática, a menos que haja aceleração exageradamente acentuada do trânsito no intestino fino e grosso. Do suco pancreático depende a digestão do tecido muscular. O papel digestivo do suco gástrico sobre este tecido é indireto, através da digestão do tecido conjuntivo, com o que se liberam as fibras mus- 
culares que oferecem, então, maior superfície de ataques ao suco pancreático.

Quando as fezes de regime de prova contém restos de tecido muscular mal digeridos em certa abundância, deve-se inferir a existência de um transtorno da digestão pancreática. Fato idêntico se deduz em relação á digestão gástrica quando aparece nas fezes tecido conjuntivo, como já afirmamos. Se, como ocorre com certa frequência, houver concomitância de deficiência do quimismo gástrico e pancreático, é facil compreender que aparecerão nas fezes restos tanto de tecido muscular como de tecido conjuntivo.

A prova dos núcleos ideada por Schmidt, para evidenciação de insuficiência pancreática, hoje se acha um tanto abandonada, por dificuldades de identificação dos núcleos nas fezes.

Restos de amido e de celulose: Nas fezes de um indivíduo normal, com alimentação mixta habitual, podem se encontrar substâncias amiláceas, dependendo a sua quantidade da facilidade com que os sucos digestivos podem atacar o envoltório celulósico do amido nelas contido. Assim sendo, nada se pode julgar com segurança do encontro de amido nas deposições de um paciente que não esteja submetido a um regime padrão. Nêste regime o amido se acha incluido em celulose facilmente digerivel our inteiramente livre de celi1ose. Daí a importância de se sujeitarem os examinandos ào regime de prova. Sob este regime, normalmente, nunca se eliminam a não ser traços de amido nas fezes, assim mesmo, já parcialmente atacado. Portanto, o encontro de amido em certa quantidade nas fezes de paciente com regime de prova, deve ser considerado patológico. Constitue o principal carater microscópico das fezes da dispepsia fermentativa. O amido pode ser encontrado de duas maneiras: ou isoladamente (amido amorfo), ou envolto em membrana de celulose (amido incluido, das. células da batata, do feijão, etc.). $\mathrm{O}$ amido amorfo se apresenta sob a forma de pequenos blocos isolados, homogeneamente corados em azul pelo lugol. $\mathrm{O}$ amido incluido se acha disposto em grãos pequenos e numerosos no interior de células da batata, do feijão, corados tambem em azul pelo lugol. Ao lado do anido ainda íntegro, reconhecivel pela côr azul que toma com o lugol, podemos encontrar tambem, eritrodextrina que assume coloração rósea com o lugol, constituindo já uma fase de digestão daquele hidrocarbonado, como se sabe.

Sob um outro critério, podemos distinguir o amido cozido, isto é, que já sofreu a ação dos processos culinários e o amido ainda crú, tal como o da banana crua, da farinha que salpica a superfície do pão. Este amido crú se caracteriza por se mostrar sob a forma de grãos organizados em camadas concêntricas claras e escuras, mais ou menos evidentes. Alssumem fortemente o iodo tomando coloração negra. Os grãos mais conservados possuem ainda o hilo central ou pouco excêntrico, quando examinamos o material "in natura", não tratado pelo 1ıgo1. O amido crú é birrefrangente, o que não se dá com o cozido. 
Goiffon insiste na differenciação do amido crú e cozido, ambos com significação fisiopatológica e propedêutica diversa. A seu ver o amido cozido, sobretudo o amorfo; é atacado pela amilase salivar e, principalmente, pela amilase pancreática, estando, quasi totalmente digerido quando o conteudo intestinal chega ao ceco. Ao contrário, o amido incluido chega em quantidade mais ou menos abundante ao ceco. Compreende-se que a sua digestão seja mais dificil que a do amido amorfo, em razão da "casca" de celulose que o envolve dificultar o seu ataque por parte da amilase pancreática. A sua digestão só se completa após a dissolução que o envóiucro de celulose sofre, mercê da flora fermentativa, particularmente abundante no ceco. Goiffon considera como componente característico do conteudo da região cecal, o amido incluido (amido propriamente e celulose envolvente).

Eis porque Goiffon faz do achado nas fezes deste amido incluido, e portanto tambem da celulose digerivel que o envolve, o principal testemunha de evacuação rápida dos colons, a partir do ceco. Já a presença nas fezes de amido amorfo será đevida ou a uma insuficiência pancreática ou a esvasiamento intestinal acelerado a partir do íleo. Os demais dados coprológicos resolverão a dúvida.

O amido crú tem o mesmo valor semiótico que a celulose digerivel (celulose dos feculentos, da cenoura), só aparecendo ambos nas fezes em quantidades mínimas normalmente. A sua digestão se faz graças á ação bacteriana da flora iodófila do intestino grosso, sendo tanto mais completa quanto maior a sua permanência nas primeiras porções do colon. Já dissemos que faz Goiffon de sua presença nas fezes o índice fundamental de evacuação rápida do intestino grosso a partir do ceco.

Além da aceleração do trânsito, pode determinar o aparecimento de celulose digerivel nas fezes um excesso de fermentação ou de putrefação, em virtude dos meios demasiadamente ácidos ou alcalinos, dificultarem a acção da fiora sacarolítica. Isto se dá mais comumente na dispepsia fermentativa, donde a presença do amido incluido, do amido crú e da celulose digerivel (membrana das celulas dos feculentos e da cenoura) nas fezes ser o principal sinal microscópico desse importante e complexo quadro clínico.

Corpos gordurosos: Proveem eles da manteiga, do leite e da carne ingeridos nas refeições de prova. Sob três formas podem os corpos gordurosos ser notados nas fezes: de gorduras neutras, de ácidos. graxos e de sabões. Como se sabe, as gorduras neutras são éteres glicéricos, isto é, corpos resultantes da combinação da glicerina com ácidos graxos, dos quais os mais encontrados nos nossos alimentos. habituais são os ácidos palmitico, esteárico, olêico e butírico.

Os sabões nada mais são que combinações desses ácidos graxos. com metais, distinguindo-se pela frequência nas fezes, o cálcio e o magnésio. A identificação dos 3 tipos de corpos alifáticos nas fezes é tarefa dificil, tendo vários AA. ideado diversos métodos de colorações 
específicas, dada a variabilidadè morfológica, mormente dos sabões e dos ácidos graxos.

Tem nos prendido a atenção ha certo tempo a identificação dos sabões e dos ácidos graxos nas fezes, dada a importância propedêtutica que se procura conferir a estas substâncias, principalmente em razão das idéas de. Porges, dando-lhes valor no diagnóstico das enterites. Dos vários processos que têm sido utilizados e aconselhados pelos diferentes AA., temos obtido melhores resultados com o método de Heupke, isto é, coloração das fezes com o azotato de cobre em solução saturada e com a solução alcoólica (álcool a 700) saturada de Orleans Grübler. Ao iniciarmos nossos estudos com estes métodos, uma primeira dificuldade se nos deparou: a obtenção do Orleans Grübler. Liembrou-nos, entretanto, o dr. Oria que este corante era retirado do urucu, tendo o urucueiro o nome de $\cdots$ orelana". Extraimos, então, a matéria corante do urucu, seguindo as indicações do dr. Hilário da Veiga Carvalho, em trabalho que realizou sobre o emprego do urucu em técnica histológica (1).

Com este corante as gorduras neutras adquirem coloração amarelo-clara; de intensidade diferente de uma gotícula para outra.

A coloração dos sabões e idos ácidos graxos temos conseguido com o azotato de cobre. Para êxito da coloração achamos de importância a observância dos seguintes cuidados:

a) Diluição das fezes em água adicionada aos poucos, até que o material ardquira a consistência de mingau grosso.

b) Retirar da parte mais superficial duas ou três gotas do material e misurá-las bem sobre uma lâmina com 1 ou 2 gotas da solução aquosa saturada de azotato de cobre. é importante colher o material da superfície.

c) Aquecer até à ebulição por alguns segundos entre lâmina e lamínula. Deixar o material esfriar e observar ao microscópio.

Com esta técnica os sabões e ácidos graxos se apresentam corados em verde brilhante e'm forma de cristais ou de grumos de aspecto finamente granuloso, de tamanhos variaveis.

"In natura" reputamos dificil e passivel de erro a pesquisa dos corpos gordurosos. Embora as gorduras neutras tenham sempre a forma de gotas, bem delimitadas, de tamanho variavel, esta mesma forma pode ser assumida pelos ácidos graxos, ainda que se apresentem com maior frequência como agulhas muito finas e longas. De muito maior dificuldade é o reconhecimento dos sabões que podem ter as formas mais irregulares e cores variadas.

A interpretação propedêutica dos resíduos gordurosos nas fezes deve ser feita com o máximo cuidado e mais do que nunca devem ser correlacionados os resultados dos vários achados do exame copro-

(1) Veiga Carvalho, H.: Sobre o emprego do urucu (Bixa orellana) em técnica histológica; Folia Anatomica Universitatis Conimbrigensis, Vol. XII, 11.0 13, 1937 (Separata). 
lógico. Normalmente, sob regime de prova, as dejeções conteem rarissimas gotículas de gorduras neutras. São tambem raros os ácidos graxos, e os sabões. Em vários estados mórbidos se regista aumento das gorduras nas fezes. $\mathrm{Na}$ insuficiência pancreática intensa o aumento se faz predominantemente á custa das gorduras neutras, explicavel pela deficiência de lipase existente no suco pancreático. Já na insuficiência biliar (obstrução total ou parcial do colédoco) esse aumento se processa principalmente á custa dos ácidos e dos sabões. Porges, faz do excesso de sabões e de ácidos graxos nas fezes o dado de laboratório mais característico de transito rápido no delgado (enterite).

No esprú ha aumento grande da excreção de gorduras por incapacidade funcional da mucosa em absorvê-las.

Elementos de origem intestinal: Como já vimos, os eritrocitos e os globulos brancos se destroem rapidamente no intestino. Assim sendo, sempre que forem reconhẻciveis nas fezes, devem provir de lesões bem baixas (reto ou sigmoide) ou de lesões situadas mais alto, com rápido esvasiamento do intestino a partir do local ulcerado. Caso contrário, serão esses elementos destruidos e o diagnóstico da ulceração só se fará pela pesquisa dos corpos albuminoides que adeante descreveremos.

Entre os cristais de valor no exame coprológico já falamos dos cristais de oxalato de cálcio de origem alimentar. Citemós mais os

Cristais de Charcot-Leyden: Teem a forma alongada, de ponta de lança. São encontrados nas parasitoses intestinais (helmintíases e protozooses). Teem a mesma composição química (Goiffon) que as granulações específicas dos eosinófilos (sulfato de espermina). Seriam a expressão de uma eosinofilia local, coincidindo com eosinofilia sanguínea. Encontram-se nas manifestações alérgicas enterocólicas.

\section{REAÇÕES QUÍMICAS}

Além dos elementos figurados já descritos, observaveis macro ou microscopicamente, a massa fecal pode conter, várias substâncias dissolvidas que são surpreendidas por meio de reações químicas. Trata-se de pigmentos biliares, hemoglobina, corpos protêicos, fermentos.

Pigmentos biliares: As fezes podem conter estercobilina, estecobilinogênio ou mesmo a bilerrubina ainda não transformada naqueles derivados. A verificação do estado em que se acham esses corpos se faz por meio de dois reativos: solução saturada de sublimado corrosivo é pelo ácido clorílrico mais percloreto de ferro (reação de Grigaut).

"Reação do sublimado": A um tubo de ensáio contendo 10 ou $15 \mathrm{cc}$. de uma diluição de fezes a $5 \%$ aproximadamente, acrescentam-sé 2 .cc. de uma solução aquosa saturada de sublimado. Se 
as fezes contiverem estercobilina ou estercobilinogênio o líquido sobrenadante e sobretudo o depósito se coram èn vermelho-tijolo e em. verde se estiver presente a bilerrubina ainda não transformada. $\mathrm{Na}$ ausência de pigmento biliar nenhuma mudança de côr será notada. Para o desenvolvimento đa coloração podem ser necessários desde alguns minutos até algumas horas, em geral de 15 a 20 minutos (1).

"Reação de Grigaut": Num tubo de ensáio, a partes iguais da mesma diluição fecal da reação anterior e de ácido cloridrico adi-. cionam-se, após ligeiro aquecimento, algumas gotas de percloreto de ferro diluido. Se houver mesmo traços de bilerrubina, aparecerá côr verde. A côr vermelha atestará presença de estercobilina. $\mathrm{Na}$ ausência de pigmentos não haverá reação corada:

A primeira reação é mais sensivel para a pesquisa da estercobilina e a segunda para a da bilerrubina.

Para a interpretação dos resultados desta reação é necessário sa-ber-se que a transformação da bilerrubina em estercobilina se faz. na região ileocecal. A bilerrubina é caracteristica do conteudo dodelgado. A sua presença nas fezes indica, portanto, eśvasiamento muito rápido a partir do ileo terminal e do ceco. A presença de estercobilina no material eliminado, entretanto, permite concluir que o transito cólico não se acha acelerado. Segundo Goiffon, a contradição ențre a reação do sublimado, denotando estercobilina e a do percloreto, mostrando bilerrubina, indica estar o pigmento em. vias de transformação, permitindo este fato concluir trânsito rápido nos colos apenas.

Além destas noções a respeito do trânsito intestinal, fornece a pesquisa dos pigmentos biliares nas fezes o meio mais seguro de seafirmar a existencia de fezes acólicas (obstrução total do colédoco), permitindo distinguí-las das fezes claras, ás vezes encontradas em. dispepșias putrefativas, em virtude de uma redução excessiva da estercobilina. Não esquecer, entretanto, que nas icterícias obstrutivas intensas os pigmentos biliares podem se eliminar pelas paredes intestinais e as fezès, assim como certas secreções como a saliva. e o suor, podem contê-los. Seria errôneo, nestes casos, diagnosticar -obstrução parcial das vias biliares baseados no encontro de estercobilina nas fezes.

Sangue e hemorragias ocultas: $\mathrm{O}$ aparecimento nas evacuações: de sangue perceptivel macro ou microscopicamente depende, como vimos, do ponto do tubo digestivo lesado e da rapidez com que se elimina o conteudo intestinal a partir desse ponto. Quanto mais baixa a lesão e quanto mais acelerado o trânsito, tanto maiores as possibilidades do sangue se apresentar "vivo" nas fezes. Daí a verificação de sangue nas deposições ser mais comum nas colites: terminais, nas hemorroidas, etc. Goiffon admite a possibilidade de:

(1) Costumamos realizar a leitura após 24 horas. 
eliminação ide sangue, como tal, em hemorragias duodenais ou gástricas, com aceleração muito grande do trânsito entero-cólico. Fóra destas eventualidades excepcionais, entretanto, o sangue derramado na luz do tubo digestivo transforma-se rapidamente, destruindo-se as hemácias. Dependendo da maior ou menor quantidade de hemoglobina e derivados misturados ao conteudo intestinal, as fezes adquirem côr mais ou menos escura, até a preta - melena. Para a pesquisa nas fezes da hemoglobina e derivados imaginaram-se vários métodos, repartidos em dois grupos: os métodos que evidenciam os pigmentos. sanguíneos pelas suas qualidades peroxidásicas, e os processos. que os identificam pelas suas características espectroscópicas. Os. primeiros, pelas facilidades técnicas, são os únicos usados nos laboratórios clínicos. Temos usado a reação de Kastle-Meyer e a reação da benzidina, de preferência a primeira.

Para a reação de Kastle-Meyer usa-se o reativo do mesmo nome, que contém, em meio alcalino, a fenolftalleina já reduzida pelo zinco em pó.

O reativo é preparado da forma seguinte:

Fenolftaleina $\ldots \ldots \ldots \ldots \ldots \ldots \ldots .2$ grs.

Lexivia de potassa ............ 60 grs.

Agua $\ldots . \ldots \ldots \ldots \ldots \ldots \ldots$............ 100 cc.

Leva-se á ebulição e então, lentamente, adiciona-se pó de zinco até descoramento total da solução. Filtrar e guardar em vidro bem fechado com um pouco de pó de zinco no fundo. Num tubo de ensáio contendo alguns centímetros cúbicos de uma solução diluida. de fezes, adicionar $1 / 2$ a $1 \mathrm{cc}$. do reativo e duas gotas de agua oxigenada. $O$ aparecimento quasi imediato de côr vermelha atesta a atividade peroxidásica (oxidação da fenolftaleina reduzida) e, portanto, presença de pigmentos șanguíneos.

- Para a pesquiza de hemorragias ocultas é necessário submeter-se o paciente previamente 3 a 5 dias a regime absolutamente isento de carne de qualquer espécie. No regime não deve tambem figurar pão que contenha fermentos (e portanto, oxidases) nem verduras, em razão desta conter clorofila, que possue propriedades peroxidásicas. O melhor regime será aquele que contenha arroz, pão branco, farinhas, leite, batatas, frutas cozidas, sucos de frutas, ovos, queijo, chá e café. Dada a possibilidade das fezes conterem pigmentos sanguineos ainda no $3 .^{\circ}$ dia do regime (Von Noorden) é conveniente examinar o material vários dias a partir do terceiro dia, ou 2 ou 3 vezes a partir do $5 .^{\circ}$ dia. Von Noorden recomenda examinar-se, sempre que possivel, material tanto da superfície, como do interior do bolo fecal. O encontro de sangue só na superficie seria importante argumento em favor de que ele proviria de um local situado: além do angulo hepático do colo, não tendo tido tempo de se misturar totalmente ao conteudo intestinal. 
A'fastadas causas extra-intestinais que possam ocasionar derramamento sanguíneo intra-intestinal (púrpuras, hipertensão porta) e certificados de que o sangue não provém da garganta, das fossas nasais e dos pulmões, a positividade da pesquiza da hemoglobina é fator que fala a favor de ulceração em um ponto quálquer do tubo digestivo (ulcus, neoplasias). $O$ valor da verificação é maior quando repetida várias vezes.

Lembremos, de passagem, os trabalhos de Boas, demonstrando maior sensibilidade da pesquisa da deuteroporfirina do que da hemoglobina, no diagnóstico e evolução das úlceras gastro-duodenais.

Substâncias albuninoides: Em condições patológicas podem as fezes conter corpos albuminoides. E' questão pacífica admitir-se que tais substâncias não sejam de origem alimentar, a não ser que haja sinais de excessiva aceleração do trânsito intestinal, mas provenham de secreção ou de exsudatos da parede intẹstinal inflamada ou mesmo infectada. Possuimos atualmente, na pesquisa destes corpos azotados, recursos propedêuticos dé valor inestimavel para o diagnóstico das entero-colites com substrato anatómico.

Entrevistos já por Schimidt, foram esses corpos protêicos sistematicamente estudados por Goiffon, que conseguiu classificá-los em dois grupos: as proteinas ou albuminas íntegras e as proteinas em estado mais ou menos avançado de degradação. A identificação de cada um desses corpos se faz por meio de reativos especiais. Para as proteinas íntegras: usamos o ácido acético ao $1 / 3$ para a mucina e o ácido tricloroacético a $20 \%$, para proteinas íntegras que não a mucina. A pesquisa das proteinas degradadas se faz com uma solução aquosa saturada de sublimarlo (cloreto mercúrico). Em um tubo de ensaio colocam-se 10 a $15 \mathrm{cc}$. de uma diluição de fezes a $3 \%$ aproximadamente e $2 \mathrm{cc}$. dos reativos mencionados acima, em cada tubo. Usamos ainda um tubo testemunha contendo a diluição fecai e 2, cc. de água distilada. A positividade da reação é dada pela formação de um precipitado, em forma de coágulos, e de um líquido límpido sobrenadante ou interposto aos coágulos.

Com o ácido acético consegue-se surpreender á mucina produzida em proporções anormais pela mucosa do colo irritado, mesmo em casos em que o muco não seja visivel a olho nú.

Com o ácido tricloroacético precipitam-se as proteinas complexas e a mucina. Positiva esta reação e negativa a do ácido acético, conseguimos saber que as fezes conteem proteinas ainda não degradadas, que não a mucina. Estas proteinas são, ou do sangue ou de processos colíticos baixos, ou mesmo de lesões situadas mais alto, desde que haja esvasiamento cólico rápido, não havendo tempo dessas proteinas se degradarem.

A reação com o sublimado é ainda de maior importância. Evidencia nas fezes proteinas já degradadas, como, por exemplo, os corpos albuminoides existentes no pús. A propósito desta reação, 
por um lado, e da medida da catalase nas fezes, por outro lado, tem aparecido imenso número de trabalhos nos últimos anos. Todas estas pesquisas chegaram a resultados aproximadamente concordantes, deduzindo-se que a positividade da reação do sublimado (reação de Triboulet) e o aumento do poder catalásico das fezes (medido pelo volume de oxigênio proveniente da decomposição da água oxigenada que se forma em certo tempo, geralmente duas horas, quando as fezés são misturadas com aquele composto.) são os dados propedêuticos mais seguros de que dispomos para o diagnóstico de processos ulcerosos entero-cólicos. Realizadas as provas em condições adequadas (regime prévio sem carne, ausência de hemorroidas, etc.), a positividade de uma delas e com maior razão das duas, é sinal absolutamente certo de uma entero-colite ulcerosa. A negatividade das provas quasi sempre (ha pequeno numero ide exceções) exclue substrato anatômico a uma síndrome diarrêica. As reações não se aplicam ao diagnóstico de ulcerações gastro-duodenais.

Compreende-se o valor imenso que teem estes recursos propedêticos mormente nos tuberculosos. E' sabido que os tuberculosos pulmonares teem distúrbios intestinais com grande frequência. E problema eriçado de dificuldades é conhecer-se exatamente a natureza dessas perturbações, se de ordem puramente funcional ou se representam realmente uma localização intestinal da infecção tuberculosa. $\mathrm{Da}$ solução dependem prognóstico e conduta terapêutica inteiramente diversos.

Procurando dar maior segurança ao diagnóstico das colites ulcerosas, Goiffon tem estudado mais uma reação. E' a pesquisa dos corpos protêicos mediante o ácido fosfotúngstico. Revelaria corpos ainda mais degradados do que aqueles surpreendidos pelo sublimado. Seria de grande valor essa reação no diagnóstico de processos ulcerosos do colo direito, sem trânsito acelerado (Goiffon). Ainda não ha, entretanto, juizo definitivo acerca do valor real da prova.

Flora microbiana e dosagens químicas: Tem sido continuamente objeto de estudos aprofundados o conhecimento da flora intestinal. Os esforços teem se dirigido no sentido de se saber se os germes aí existentes habitualmente, vivendo em comensalismo, podem se tornar patógeenos, determinando enterites ou colites. As op1niões ainda se dividem, provindo as divergências das dificuldades em se encontrar um método, não passivel de críticas severas, para se abordar o problema. Os principais obstáculos á solução do problema são os seguintes: $1 .^{\circ}$ ) A flora intestinal eliminada naturalmente com as fezes é constituida quasi totalmente de germes mortos, não representando, os que se cultivam, nem em quantidade, nem em proporção, o verdadeiro estado da flora em sua séde de maior vitalidade, isto é, na região ileo-cecal. Para diminuir esta dificuldade alguns autores procuram uma evacuação artificial desta região por meio de um purgativo, examinando a segunda ou terceira parcela de fezes eliminadas. Embora o método possa ser admitido, com certas res- 
trições, do ponto de vista científico, oferece inconvenientes, muitas vezes sérios, na prática diária.

$\left.2 .^{\circ}\right)$. As qualidades dos meios de cultura dos germes "in vitro" são diferentes das condições realmente existentes no meio intestinal. Assim sendo, não se pode afastar a seguinte objeção: será que os 'germes que se desenvolveran em maior escala nesses meios de cultura são os que no seu/"habitat" natural eram os dotados de maior vitalidade e virulência e predominavam numericamente; ou as condições dos meios artificiais de cultura impediram o crescimento dos mais numerosos e favoreceram o dos mais raros?

3. ${ }^{\circ}$ ) Além destas duas objeções fundamentais, poder-se-ia ainda dizer que o estudo da flora intestinal exigiria, em laboratórios clinicos, a existência de meios de isolamento muito delicados e dificeis de serem utilizados em grandes proporções. E' sabido que enquanto certos representantes da flora são facultativamente anaeróbios, outros. o são estritamente.

Assim sendo, a orientação que se mostrou mais fecunda em resultados práticos foi a de se distinguirem dois grupos de germes. na flora intestinal: Os germes de cuja atividade sobre os alimentos hidrocarbonados resultam produtos ácidos e os germes que, atacando as proteinas, produzem, ao lado de amoníaco, corpos como o indol, o escatol, o fenol, aos quais se atribue a maior culpa nas intoxicações enterógenas.

Estes dois grupos de germes vivem em constante equilíbrio e do predomínio de um deles resultam estados mórbidos que foram denominados dispepsias, desde Ad. Schimidt.

E nos exames coprológicos tem-se uma idéa bastante exata da orientação da flora nó sentido alcalino ou fermentativo dosando-se nas fezes os produtos oriundos da atividade de um e outro grupo. E' portanto um meio indireto de se avaliar o estado de desenvolvimento da flora intestinal e que satisfaz as necessidades clínicas.

Estão hoje mais generalizados os processos de dosagem ideados pela escola francesa de Nepveux, Roux e Goiffon, em virtude destas dosagens terem fornecido ensinamentos mais satisfatórios sob os aspectos diagnóstico e terapêutico. As provas de fermentação e de putrefação estabelecidas por Schimidt, recomendadas por Von Noorden, estão hoje abandonadas.

A descrição detalhada dos processos de dosagem dos ácidos de fermentação e do amoníaco será encontrada no livro de Goiffon, "Manuel de coprologie clinique". Este A. estabeleceu como valores normais para os produtos de fermentação 14 a $16 \mathrm{cc}$. (volume de ácido clorídrico N/10 em cada 10 grs. de fezes). Tem valor clínico tanto o aumento quanto a diminuição desta taxa. O aumento para 20 ou 30 ou mais cc. é dado importante para o diagnóstico de dispepsia fermentativá, sendo as fezes tambem, em geral ácidas ao tor- 
nasol e contendo restos de amido e de celulose digerivel em abundância. Entretanto, pode-se encontrar reação neutra ou alcalina ao tornasol, com taxa alta dos ácidos de fermentaçã̃o como assinalamos atrás. Trata-se, como vímos, de casos em que o excesso de ácidos promove hiperssecreção cólica. Ora, as secreções cólicas, alem de serem ricas em álcalis, constituem bom meio de desenvolvimento da flora proteolítica. O amoníaco proveniente desta flora e os álcalis referidos são suficientes para meutralizar ou mesmo superar os ácidos, donde a reação neutra ou alcalina.

Goiffon dá as seguintes quatro eventualidades de abaixamento لa taxa dos ácidos orgânicos: 1) nos casos em que as putrefações se iniciam precocemente havendo, então, dificuldade ao desenvolvimento da flora fermentativa; 2) nas diarréas com teor excessivo de água nas fezes, havendo diluição dos ácidos; 3) nas fezes enduerecidas, o abaixamento sendo provocado por subtração da massa fecal de substâncias soluveis; 4) nas evacuações em que se reconhecem caracteres do conteudo do delgado, em que as fermentações não tivera mtempo de se desenvolver.

Queremos ainda chamar a atenção para o valor que representa o encontro de clostridios nas fezes. São bacterias de fórma variavel, alongada ou arredondada, contendo no seu interior grânulos coroaveis em azul pelo lugol. A sua presença nas fezes, em certa quantidade, é indicio de predomínio da flora ácida, e, portanto, de dispepsia fermentativa.

A taxa normal de amoníaco varia, pelo método de Goiffon, até $3 \mathrm{cc}$. Valores maiores, principalmente superiores a $5 \mathrm{cc}$., indicam putrefações anormais. Constituem o principal dado da dispepsia de putrefação. E' necessario, entretanto, lembrarmos-nos de que o amoníaco nas fezes se acha livre e combinado. Sob a forma livre este corpo é facilmente absorvido pela mucosa, sendo-o mais dificilmente quando combinado (fosfato amoníaco-magnesiano). Donde, considerarem-se os valores achados, como já em parte diminuidos por esta possivel absorção.

A existência de casos mixtos, de dispepsias fermentativas e putrefativas, teem sido assinalados com frequência.

Dadas estas noções gerais a respeito dos aspectos fundamentais. do exame coprológico, exporemos, a título de exemplo, 2 observações daquelas em que tivemos resultado favoravel graças à orientação que nos deu o exame coprológico:

\section{OBSERVAÇÃO N. $0^{\circ} 1$}

J. M., 31 anos, casado, brasileiro, de S. Paulo.

H. M. A. - Iria 10 anos vem tendo periodicamente surtos diarrêicos: 2 a 3 dias com 4 a 5 evacuações diárias, fezes geralmente amarelo-claras, 
raramente escuras, sendo exoneradas com grande quantidade de gases. Apenas notou de restos alimentares, verduras, algumas vezes. Nunca notou sangue, raramente pequena quantidade de catarro. Não tem puxos, mas acusa ardor no anus ás evacuações. Sente cólicas, por vezes violentas, en todo o abdomem, mais intensas em torno do umbigo. Os surtos sobreveem sem causa aparente. Nos intervalos passa com prisão de ventre, ficando até 3 dias sem evacuar, sendo as fezes em pelotes miudos, sem catarro. Usa com frequência laxativos. Os surtos diarrêicos se repetem cada 2 a 4 mệses. Como o ultimo período de diarréia já esteja durando 20 dias, tendo alguns dias até 6 evacuações e tenha eliminado catarro e emagrecido muito, resolveu prợcurar o Ambulatorio de Gastro-Enterologia. Anteriormente dominava as diarréas com remédios caseiros. Não refere febre nem icterícia. Perde o apetite nos dias de diarréa apenas. Sente com frequência, principalmente nos dias que antecedem um surto diarrêico, roncos em torno do umbigo e a salivação abundante.

Interrogatório sobre os diversos aparelhos: Assinalar apenas nervosismo grande do paciente desde moço.

Antecedentes pessoais e hábitos: Afirma que desde criança tinha "intestino fraco", pois bastava abusar um pouco de doces ou de frutos, para ter um ou dois dias de diarréa. Entretanto, eram distúrbios passageiros, evacuando regularmente fora deles. $\mathrm{Ha} 10$ anos é que seus males se açentuaràm.

Nega moléstias venéreo-sifilíticas. Teve sarampo e coqueluche. Não é nem foi etilista. Tabagista moderado. Come pouca verdura, por esta the fazer mal. Sempre residiu na capital.

Exame físico: Indivíduo normolíneo, emagrecido, abatido, mucosas pouco coradas. Dentes mal conservados, não permitindo bôa mastigação. Pulso 80 por minuto, tenso, regular.

$$
\text { P. A.: } \mathrm{Mx} .=11,8 \times \mathrm{Mn} .=7,5 \text {. }
$$

Abdomem: Assinalar apenas gargarejo no ceco e no sigmoide. Não ha pontos dolorosos. Figado e baço não palpaveis.

Nada de anormal nos outros aparelhos.

\section{EXAME COPROLÓGICO}

\section{Caracteres exteriores e exame macroscópico}

Consistência: Pastosa

Fórma: Moldada ao recipiente.

Reação: Ácida.
Cheiro: Sui-generis

Aspecto: Homogêneo

Côr: amarelo-escura.

Não se notam restos alimentares de origem animal, nem vegetal.

Como restos de origem intestinal: Raros e pequenos grumos de muço.

\section{EXAME MICROSCóPICO}

Restos de alimentos animais: Algumas fibras musculares bem digeridas. Pequena quantidade de gorduras neutras, de ácidos graxos e de sabões.

Restos de alimentos vegetais: Amido amorfo em regular quantidade, sendo o amido incluido muito máais abundante.

\section{REAÇŌES QUIMICAS}

Estercolibilina: presente.

Bilerrubina:

Mucina: traços.
Albumina soluvel: traços leves. Albuminas degradadas:

Sangue: pesquisa prejudicada.

\section{DOSAGENS QUIMICAS}

Ácidos organicos totais: $36,2 \mathrm{cc}$.

Amoníaco: $4,5 \mathrm{cc}$. 
FLORA INTESTINAL:

Grande quantidade de clostridrios.

\section{EXAME PARASITOLÓGICO}

Ovos de helmintos:

Protozoários: Giardias intestinalis. Em vários outros exames de fezes não foram encontradas amebas nem outros parasitos intestinais.

Cultura de fezes para o grupo coli-tifo-disentérico: negativa.

\section{COMENTÁRIOS}

Trata-se de um caso de dispepsia intestinal fermentativa. $\mathrm{O}$ exame coprológico indica os principais caracteres deste quadro mórbido: Reação ácida das fezes; grande quantidade de amido e de celulose digerivel; aumento evidente dos ácidos totais de fermentação, abundância de clostridios."

Nenhuma etiologia certamente definida foi encontrada', a não ser que se admita poder patogênico á Giardia intestinalis.

Os principais dados coprológicos para o diagnóstico de dispepsia. fermentativa, ficam então bem assinalados.

Obtivemos ótimos resultados com o tratamento dietético e com. alcalinizantes.

\section{OBSERVAÇÃO N.० 2}

A. M., 46 anos, casada, brasilęira, branca, de S. Paulo.

H. M. A.: Ha 3 anos teve um surto diarrêico: 5 ou 6 dias com: 4 a 6 evacuações diárias, líquidas, com pouco muco, sem puxos e dôres em cólica em todo o abdomem, mais intensas no hipogastrico. Desde então nunca mais seu intestino funcionou bem. Ora passa com prisão. de ventre, precisando tomar laxativos. Três ou quatro vezes por ano. tem "descargas" iṇtestinais: passa 4 ou 5 dias com 6 ou 7 evacuações, liquidas, ou pastosas, amarelo-escuras, com um pouco de catarro, sem. sangue. Como o ultimo surto dure já 10 dias, com os caracteres referidos, resolveu procurar médico. Não teve febre. Emagreceu pouco. Só. nos surtos de diarréa perde o apetite. Não refere disturbios post-prandiais. $\mathrm{Ha} 5$ anos sente peso no estomago depois das refeições, principalmente. quando come carne, gordurosos e queijo.

Antecedentes pessoais e habitos: Sarampo. Teve três filhos, nenhum aborto. Até $o$ início da moléstia atual nunca teve distúrbios gastro-intestinais. Não é etilista nem tabagista.

\section{EXAME .FISICO GERAL}

Indivíduo normolíneo, de bôa aparência geral, péle quente e úmida; mucosas pouco coradas. Não ha icterícia. Sistema ganglionar não aumentado.

$$
\begin{aligned}
& \text { P. A.: } \mathrm{Mx} .=13 \times \mathrm{Mn} .=8,5 \quad \text { Pulso }=82 \\
& \text { Temperatura }=36^{\circ}, 7^{\prime} \quad \text { Resp. }=20 \\
& \text { Peso }=50 \mathrm{Km}, 2 \quad . \quad \text { Altura }=1 \mathrm{~m}, 60
\end{aligned}
$$




\section{EXAME ESPECIAL}

Do Exame especial dos vários aparelhos assinalar apenas algumas raizes infectadas, dentes com várias falhas, não permitindo bôa mastigação. Amídalas não aumentadas.

Abdomem sem pontos dolorosos, mesmo á palpação deslisante profunda. Figado è baço não palpaveis.

\section{EXAMES DE LABORATORIO}

\section{EXAME COPROLOGICO}

Caracteres exteriores e exame macroscopico

Consistencia: Pastosa.

Cheiro: pútrido

Forma: Moldada ao recipiente.

Reação: Alcalina.

Aspecto: homogeneo.

Côr: Marron-escura

Restos de tecido conjuntnvo em grande quantidade. Pequena quantidade de muco, de aspecto gelatinoso.

\section{EXAME MICROSCÓPICO}

Restos alimentares animais: Numerosas fibras musculares bem digeridas e raras mal digeridas. Rarissimas gotículas de gorduras neutras e raros grumos de sabões.

Restos de alimentos vegetais: Blocos pequenos e muito raros de amido amorfo.

Restos de origem intestinal: Raros leucocitos e raras hemacias.

\section{REAÇÕES QUIMICAS}

Estercobilina: presente.

Bilerrubina: ausente.

Mucina: traços evidentes.
Albumina soluvel: traços.

Albuminas degradadas: Ausent.

Sangue:

\section{DOSAGENS OUIMICAS}

Ácidos organicos totais $\ldots \ldots \ldots \ldots \quad 14,4 \mathrm{cc}$.

Amoniaco ................ $8,4 \mathrm{cc}$.

\section{EXAME PARASITOLÓGICO}

Ovos de helmintos: Ancilostomídeos.

Protozoarios: "Trichomonas intestinalis" e numerosos cistos de ameba coli (lugol).

Cultura: negativa para o grupo coli-tifo-disentérico.

\section{EXAME HEMATOLOGICO}

Globulos vermelhos ..............

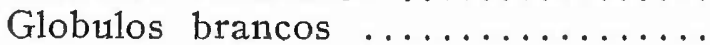

Hemoglobina

V. G. $=0,93$

$90 \%$

Contagem especifica: nada digno de nota.

\section{PROVA DE IATSCH - KALK}

Não se obteve acidês livre mesmo após injeção de histamina. Esvasiamendo do $5 .^{\circ}$ paro o $60^{\circ}$ tubo. 


\section{COMENTÁRIOS}

Como se vê, o quadro clínico fica inteiramente esclarecido pelo exame coprológico. Trata-se de um caso de dispepsia putrefativa (8,4 cc. de amoniaco) cuja etiologia podemos atribuir á aquilia gástrica (tecido conjuntivo nas fezes). O diagnóstico coprológico de aquilia foi comprovado pela prova de Katsch-Kalk, não sendo encontrada acidês livre á histamina.

Sinais indiretos de dispepsia putrefativa são o encontro de "Trichomonas intestinais" e de ameba coli, pois, como se sabe, tais protozoários vivem bem em meio alcalino.

A paciente melhorou rapidamente com o regime alimentar adequado á dispepsia putrefativa e com ácido clorídrico.

$$
* * *
$$

As considerações rápidas que fizemos são suficientes para dar uma idéa do número avultado de informações que pode fornecer o exame coprológico. Baseados neste exame foram sistematizados vários síndromas coprológicos:

a) Sindroma da insuficiência gástrica: Tem como sinais mais importantes o tecido conjuntivo, restos de batata e de cenouras em pedaço, cristais de oxalato de cálcio de origem alimentar. Com insuficiência gástrica pode haver concomitância de uma dispepsia putrefativa ou fermentativa.

b) Sindroma de insuficiência pancreática: Carater fundamental éo encontro de gorduras neutras em abundância e de tecido muscular mal digerido, além de volume excepcionalmente grande das. evacuações.

Qualquer um dos đesvios dispépticos podé estar associado.

c) Sindroma de insuficienicia biliar: Em que as fezes são claras, com grande quantidade de gorduras, principalmente ácidos graxos e sabões. Nas obstruções totais o principal sinal coprológico é a ausência de estercobilina e de bilerrubina.

d) Dispepsia fermentativa: Tem como sinais mais importantes: grande quantidade de amido e de celulose digerivel; elevação da taxa dos ácidos orgânicos de fermentação, geralmente associada com a reação ácida das fezes. A coloração adequada das fezes, revela predomínio da flora iodófila, sendo encontradas numerosas fórmas de clostrídios.

e) Dispepsia putrefativa: Fezes de reação bem alcalina; aumento da taxa do amoniaco. Pode haver restos de tecido conjuntivo e muscular. Cheiro pútrido e côr, em geral, escura das fezes. 
f) Sindroma entero-colitico: Tem como principais sinais a presença de albuminas soluveis, albuminas degrađadas, aumento do poder catalásico, presença de muco. A presença de albuminas degradadas e o aumento do poder catalásico permitem a na opinião dos que pudemos compulsar, o diagnóstico de colite com base orgânica, ulcerosa.

Para finalizar, devemos frisar que nunca devemos nos esquecer de que a digestão gástro entérica é função de dois fatores: atividade fermentativa e trànsito.

Todos os ensinamentos fornecidos pelo exame coprológico, em todas as suas fases (exame macrocópico, microscópico, químico, bacteriológico) devem. ser interpretados correlacionadamente, sendo necessário sempre investigar até que ponto dado achado coprológico depende de um distúrbio do trânsito, do quimismo dos vários sucos, de ambos os fatores ao mesmo tempo, de lesốes parietais, de distúrbios funcionais.

O exame coprológico, minuciosamente realizado, e interpretado com cuidado, fornece 4 ordens de ensinamentos:

a) Quimismo dos vários sucos digestivos: haja visto o encontro de tecido conjuntivo. (suco gástrico), tecido muscular (suco pancreático).

b) Trânsito gastro-intestinal.

c) Estado da parede intestinal: corpos protêicos dissolvidos, muco, catalasometria.

d) Estado da flora intestinal: os desvios para o lado ácido ou alcalino, caracterizando respectivamente, as pispepsias fermentativa e putrifativa.

$E^{\prime}$ 'desnecessario encarecer o valor destas informações no diagnóstico exato e na orientação terapêutica das várias gastroenteropatias.

\section{CARDIOSCLEROL TONICO CARDIACO ATOXICO \\ HIPERTENÇÃO ARTERIAL - MIOCARDITES - ARTERIOESGLEROSE A base de Viscum album - Cactus grandiflora - Gratoegus - Kola - Scila Rodanato de Potassa}

Amostras e literaturas a disposição dos srs. Medicos

CAIXA, 4500. INSTITUTO CHIMORGAN 